\title{
Aerial and surface rivers: downwind impacts on water availability from land use changes in Amazonia
}

\author{
Wei Weng ${ }^{1,2,3}$, Matthias K. B. Luedeke ${ }^{1}$, Delphine C. Zemp ${ }^{1,4}$, Tobia Lakes ${ }^{2,3}$, and Juergen P. Kropp ${ }^{1,5}$ \\ ${ }^{1}$ Potsdam Institute for Climate Impact Research, 14482 Potsdam, Germany \\ ${ }^{2}$ Geography Department, Humboldt-Universität zu Berlin, 10099 Berlin, Germany \\ ${ }^{3}$ Integrative Research Institute on Transformations of Human-Environment Systems, Humboldt-Universität zu Berlin, \\ 10099 Berlin, Germany \\ ${ }^{4}$ Biodiversity, Macroecology \& Biogeography, University of Goettingen, 37077 Göttingen, Germany \\ ${ }^{5}$ Institute of Earth and Environmental Science, University of Potsdam, 14469 Potsdam, Germany
}

Correspondence: Wei Weng (weiweng@pik-potsdam.de)

Received: 25 August 2017 - Discussion started: 14 September 2017

Revised: 26 November 2017 - Accepted: 29 December 2017 - Published: 1 February 2018

\begin{abstract}
The abundant evapotranspiration provided by the Amazon forests is an important component of the hydrological cycle, both regionally and globally. Since the last century, deforestation and expanding agricultural activities have been changing the ecosystem and its provision of moisture to the atmosphere. However, it remains uncertain how the ongoing land use change will influence rainfall, runoff, and water availability as findings from previous studies differ. Using moisture tracking experiments based on observational data, we provide a spatially detailed analysis recognizing potential teleconnection between source and sink regions of atmospheric moisture. We apply land use scenarios in upwind moisture sources and quantify the corresponding rainfall and runoff changes in downwind moisture sinks. We find spatially varying responses of water regimes to land use changes, which may explain the diverse results from previous studies. Parts of the Peruvian Amazon and western Bolivia are identified as the sink areas most sensitive to land use change in the Amazon and we highlight the current water stress by Amazonian land use change on these areas in terms of the water availability. Furthermore, we also identify the influential source areas where land use change may considerably reduce a given target sink's water reception (from our example of the Ucayali River basin outlet, rainfall by $5-12 \%$ and runoff by 19-50\% according to scenarios). Sensitive sinks and influential sources are therefore suggested as hotspots for achieving sustainable land-water management.
\end{abstract}

\section{Introduction}

The Amazon basin, draining an area of about 7 million $\mathrm{km}^{2}$, is the largest river basin in the world. It hosts the most extensive tropical rainforest ecosystem, covering about 5.3 million $\mathrm{km}^{2}$, which represents $40 \%$ of the global tropical forest area (Laurance et al., 2001; Aragão et al., 2014). The substantial transpiration from the canopy in addition to the evaporation contributes to abundant water fluxes to the atmosphere (Fisher et al., 2009). This atmospheric moisture eventually returns to the land and contributes about 25-35\% of the basin's rainfall and 48-54\% of the regional rainfall (Salati and Nobre, 1991; Eltahir and Bras, 1994; Trenberth, 1999; Bosilovich and Chern, 2006; Van Der Ent et al., 2010; Zemp et al., 2014). When regulating the water cycle in the region, the Amazon forests are a key component of the regional but also global climate system (Foley et al., 2003, 2005; Meir et al., 2006; Snyder, 2010; Anderson-Teixeira et al., 2012).

It is uncertain how the ongoing land use change influences the operation of this ecosystem and its climate regulations (Pielke et al., 2002; Foley et al., 2007; Chapin et al., 2008; Soares-Filho et al., 2014). Since the 1960s, there has been substantial clearing of the Amazon forest for agricultural purposes; about $15 \%$ of the Brazilian Amazon rainforest has been cleared (INPE, 2017). Deforested areas are most often (80\%; Veiga et al., 2002) used as pastureland. Rice, cassava, maize, and soybean cropping have also driven deforestation (Nepstad et al., 2006; Barona et al., 2010). Soarse-Filho et al. (2006) have projected a loss of $47 \%$ Brazilian rain forest 
cover by 2050 under a business as usual scenario compared to the situation in 2004. Although this fast Brazilian deforestation trend has decelerated since 2004, a rebound of the deforestation rate has been observed since 2013 (Hansen et al., 2013; INPE, 2017). Moreover, a more recent Brazilian forest policy shift may allow for further deforestation in the country (Soares-Filho et al., 2014; Aguiar et al., 2016) in addition to observed increases in deforestation rates in other Amazonian countries (Hansen et al., 2013).

Through land-atmosphere coupling mechanisms, deforestation and other land use changes in the Amazon affect climate both regionally and globally (Dickinson and Henderson-Sellers, 1988; Dirmeyer and Shukla, 1994; Gedney and Valdes, 2000; Costa and Foley, 2000; Snyder, 2010). Among those changes, modified moisture fluxes to the atmosphere (Gordon et al., 2005; Silvério et al., 2015) introduce shifts in rainfall pattern and runoff regime and influence water availability (Henderson-Sellers et al., 1993; D'Almeida et al., 2007; Coe et al., 2011; Bagley et al., 2014; Lima et al., 2014; Swann et al., 2015; Spracklen and Garcia-Carreras, 2015). Given the spatial differences found in land-atmosphere coupling strength (Koster et al., 2004; Seneviratne et al., 2006) and continental moisture recycling (Van Der Ent et al., 2010), the water regime in some areas can be more sensitive to land use change than others. However, this spatially different sensitivity in the hydrological responses to land use change is not well understood. Indeed, water regime changes are also experienced by the downwind regions that are spatially distanced from where the land use change is taking place (Pires and Costa, 2013; Bagley et al., 2014; Badger and Dirmeyer, 2015; Keys et al., 2016; Pitman and Lorenz, 2016; Zemp et al., 2017b). Thus, it requires investigation into both the sinks and the sources of the moisture flows to understand this spatial difference. Such an investigation will advance the understanding of land use change impacts on the water cycle and is necessary in order to identify hotspots for conservation policy targets fulfilling the Sustainable Development Goals (the SDGs), goal 6 ("Ensure access to water and sanitation for all") and goal 15 ("Sustainably manage forests, combat desertification, halt and reverse land degradation, halt biodiversity loss"), for example.

The most direct way of portraying the airborne moisture flows is using diagnostic models driven by observation data (or observation-based climatic data for data-scarce regions). In the present study, we utilize a moisture recycling tracking algorithm to structure the moisture flow for exploring spatial heterogeneity in land use change impacts on the rainfall and runoff in Amazonia. Moisture recycling describes the contribution of local evaporation to local precipitation and was investigated in earlier studies by utilizing bulk models to partition moisture recycling in the water cycle within an area of interest (Brubaker et al., 1993; Eltahir and Bras, 1996; Trenberth, 1999). Moisture tracking tools have been further developed to describe the course in which evapotranspirated moisture travels through the atmosphere and precipitates in downwind regions within the area of interest, thus making the architecture of "aerial rivers" perceivable, aerial rivers being the preferential pathways of moisture flow, termed in Arraut et al. (2012) as an analogy to surface rivers. Moisture tracking recognizes teleconnection between moisture sources and sinks, which are not limited to administrative and topographical boundaries. These moisture tracking tools include isotopic tracers (Salati et al., 1979; Victoria et al., 1991; Henderson-Sellers et al., 2002; Tian et al., 2007), numerical algorithms online coupled with an atmospheric circulation model (Koster et al., 1986; Bosilovich and Chern, 2006), or offline a posteriori with reanalysis or operational data (Yoshimura et al., 2004; Dirmeyer and Brubaker, 2007; Van Der Ent et al., 2010; Tuinenburg et al., 2012; Spracklen et al., 2012; Bagley et al., 2014). Here we use an offline Eulerian numerical tracking algorithm (WAM-2layers, Van Der Ent et al., 2014; see also Sect. 2.1.1) driven by observationbased data to approach moisture flows for its relatively low computation cost but robustness in identifying the spatial pattern of moisture flow in a certain region (Keys et al., 2012).

Our objectives are (1) to explore how land use change impacts on rainfall and runoff in Amazonia can differ spatially, (2) to quantify this spatial variation, and (3) to identify the regions sensitive to Amazonian land use change.

To address these objectives, spatially different rainfall and runoff responses at moisture sinks are quantified when land use change occurs in Amazonia. Different hydrological influences that result from land use change in various moisture source areas are also calculated. Furthermore, we identify the sensitive sinks (defined here as land surface areas where the water regime is most impacted by land use change in a given upwind area via moisture recycling) and the influential sources (defined here as land surface areas where land use change exerts the strongest impacts through moisture recycling on the water regime of a given area downwind).

In the following section we describe the moisture tracking experiments and the scenarios that were utilized to analyse land use change impacts on water regimes. We also introduce the concept of the most influential precipitationsheds (MIPs), which is used for highlighting the influential sources of moisture. In Sect. 3, we present the results of identification of sensitive pairs of sinks and sources to Amazonian land use change. Then, we present the quantified impacts on rainfall and runoff by land use change in terms of sensitive sinks and influential sources. Additionally, calculation of upper bound water regime changes from hypothetical land use changes from the whole of the Amazon is also shown for further comparison. We discuss implications of our results in Sect. 4. These include the contribution of the interconnection between surface and aerial rivers to the spatial heterogeneity and the importance of aerial river conservation hotspots when compared with the upper bound. We highlight the current pressure on the sensitive regions' water availability by land use change. The uncertainties and limitations of our results are also discussed in this section. In Sect. 5, we conclude our 
Table 1. The specification of the MOD experiments which were used in our analysis to trace moisture.

\begin{tabular}{ll}
\hline & \multicolumn{1}{c}{ Specification of the MOD experiments } \\
\hline Precipitation input & Tropical Rainfall Measuring Mission (TRMM) Multisatellite Precipitation Analysis (TMPA) \\
Evapotranspiration input & Moderate Resolution Imaging Spectroradiometer (MODIS) product MOD16ET \\
Humidity and wind speeds & ERA-Interim reanalysis \\
Temporal resolution & $3 \mathrm{~h}$ \\
Spatial resolution & $1.5^{\circ} \times 1.5^{\circ}$ \\
Experiment time span & $2000-2010$ \\
Spatial domain & South American continent (land part of $\left.30-85.5^{\circ} \mathrm{W}, 15^{\circ} \mathrm{N}-49.5^{\circ} \mathrm{S}\right)$ \\
\hline
\end{tabular}

findings and show how they resonate with the current discussion in the field. We then provide suggestions for managing land use change impacts on water availability for sustainable land-water use in Amazonia.

\section{Methods}

\subsection{Outlining aerial rivers}

\subsubsection{Tracing moisture flow in Amazonia}

The moisture flow is traced by the Water Accounting Model - two layers, WAM-2layers version 2.3.01 (Van Der Ent et al., 2014), for the South American continent. With a Eulerian specification of the field, the WAM-2layers model backtracks the moisture origin of precipitation that occurs over a given area following water balance. The backtracking is based on given input data while assuming that the water reservoirs of the lower atmospheric layer and the land surface are well mixed.

The WAM-2layers distinguishes between the bottom and top atmospheric layers (separately by approximately $800 \mathrm{hPa}$ for a standard surface pressure) in the calculation of moisture flux across grid cell boundaries (Van Der Ent et al., 2014). This allows for a better capturing of the wind shear system that resulted in errors in traditional offline 2-D tracking studies with a well mixed atmosphere assumption (Goessling and Reick, 2013; Van Der Ent et al., 2013).

We use simulations from WAM-2layers from a previous moisture backtrack modelling experiment (MOD experiment; see Zemp et al., 2014). The WAM-2layers model run for the MOD experiment was on a $1.5^{\circ}$ latitude-longitude grid and the time coverage was 2000-2010. The input data of the first year were used for spin-up runs. The MOD experiment result further used in this study is the moisture transport matrix m. Its elements $m_{i j}$ describe the amount of moisture evapotranspirated from grid cell $i$ which is precipitated in grid cell $j$.

\subsubsection{Input data}

The input data for evapotranspiration (ET) and precipitation $(P)$ of the MOD experiments are based on global satellite products (see Table 1). The evapotranspiration input was derived from the Moderate Resolution Imaging Spectroradiometer (MODIS) evapotranspiration product MOD16ET (Mu et al., 2013). Based on the Penman-Monteith equation and the algorithm from Cleugh et al. (2007), global evapotranspiration is calculated as the sum of evaporation (from different soil types and interception by the canopy) and transpiration from the vegetation while environmental constraints and diurnal cycles are recognized. The calculation is based on MODIS Earth observation data inputs (land cover, albedo, and enhanced vegetation index) in conjunction with the Global Modeling and Assimilation Office (GMAO, v.4.0.0) daily meteorology data. Loarie et al. (2011) validated MOD16ET's estimation with eddy flux tower data and reported its good performance (differences in annual average of evapotranspiration are less than $4 \%$ in savannas, $5 \%$ in tropical forests, and $13 \%$ in pasture agricultural lands). The precipitation input used in the MOD experiment was the product from the Tropical Rainfall Measuring Mission (TRMM) Multisatellite Precipitation Analysis (TMPA) algorithm 3B42 version 7, in which rainfall data are acquired from multiple satellite observations including passive microwave and infrared data, which were then calibrated by global rain gauge data (Huffmann et al., 2007). These remote-sensing-based rainfall data are widely used in regions that lack ground observations such as the Amazon (Wagner et al., 2009; Su et al., 2008; Awadallah and Awadallah, 2013). This dataset has been described as robust in precipitation estimations over the Amazon region, especially at a monthly timescale (Su et al., 2008; Collischonn et al., 2008). Humidity and wind speeds were taken from the ERA-Interim reanalysis product (Dee et al., 2011). Input data have been upscaled to the spatial resolution of the WAM-2layers model and downscaled to a temporal resolution of $3 \mathrm{~h}$ using the temporal variability in the corresponding ERA-Interim products. 


\subsubsection{Structuring the precipitationsheds: the MIPs}

In our analysis, we utilize the concept of precipitationsheds and outline them for our target areas according to $m_{i j}$, the amount of moisture evapotranspirated from grid cell $i$ which is precipitated in grid cell $j$, derived from the MOD experiment as described in Sect. 2.1.1. The concept of precipitationsheds was introduced by Keys et al. (2012) as the upwind surface areas providing evapotranspiration to a specific area's precipitation. In the present study we focus on the terrestrial component of precipitationsheds because of their relevance to land use change. Intercontinental moisture transports are neglected as they have little influence in our study region (Van Der Ent et al., 2010). Recognizing the spatial heterogeneity of the contribution in the precipitationshed (Keys et al., 2014), we further extract the most influential precipitationsheds (MIPs) for our analysis. The MIP is defined here as the collection of the most important source areas of a given region's rainfall. Since it includes the most prominent contributing source areas of the evapotranspiration, the MIP governs a given proportion of a given region's precipitation with minimum land surface areas. An example of a MIP for a grid element located in the Yurimaguas area is depicted in Fig. 1. The area delimited by the 0.2 contour line is the smallest land surface contributing to $20 \%$ of precipitation in the Yurimaguas grid element from continental evapotranspiration. Outside of this area, a wider land surface area collectively contributes to the same amount, the area between 0.2 and 0.4 contour lines or the area between 0.4 and 0.6 contour lines, for example. The area governs $20 \%$ of continental moisture and is defined here as the $20 \%$ threshold MIP for the Yurimaguas grid element. Likewise, the $40 \%$ threshold MIP and the $60 \%$ threshold MIP are the areas delimited by the 0.4 contour line and the 0.6 contour line in Fig. 1. The larger the threshold value, the more insignificant contributing source areas are included. The selection of the threshold determines the MIP size and the representativeness of the most important source areas; therefore it should be chosen according to study purposes. Previous studies have suggested and discussed different thresholds to delineate a precipitationshed boundary, e.g. $70 \%$ (Keys et al., 2012) or 1\% (Keys et al., 2017) threshold of continental recycled precipitation. In the present study, we propose a threshold that is a trade-off between the relative influence on the sink's rainfall and the size of the area delimited where land use change could occur homogeneously.

Under the modelling resolution of the present study, a $40 \%$ threshold is the minimum contour value to delimit precipitationshed areas for some regions (e.g. the Andes regions). Aiming to approximate the MIP by a standard that can apply to all the grid elements, the smallest valid $40 \%$ threshold has been applied throughout our analysis.

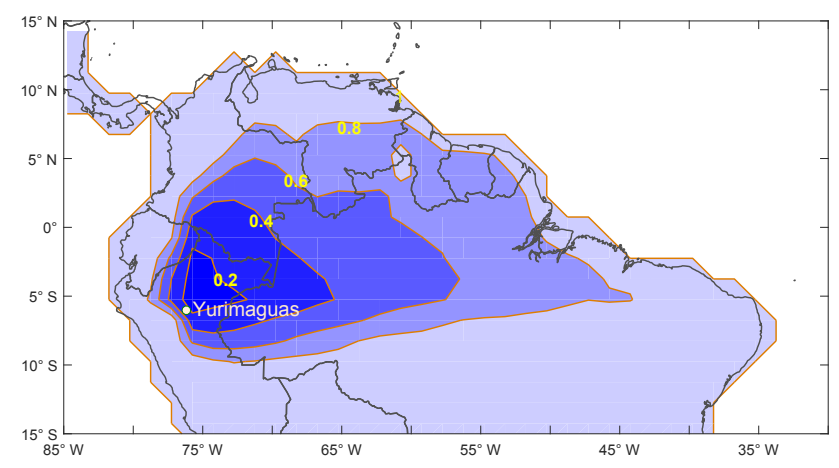

Figure 1. The precipitationshed of the Yurimaguas area. The contour value represents the cumulative fraction of Yurimaguas' rainfall that comes from the source region delimited by the contour, over the precipitation originating from the South American continent. Thus, the contour line delimiting the South American continent has the value 1 .

\subsection{Modified downwind precipitation by land use change}

We employed different land use scenarios to investigate evapotranspiration shifts introduced by various land activities and their impacts on rainfall and runoff. The proportion of precipitation changes for the grid cell $j$ in a land use scenario that occurs in the region $\Omega_{1}$ can be described as

$$
\Delta P_{j}=\sum_{i \in \Omega_{1}} m_{i j}\left(1-\frac{\mathrm{ET}^{\prime}}{\mathrm{ET}_{i}}\right),
$$

where $\Delta P_{j}$ stands for the changes in precipitation in sink grid cell $j, \mathrm{ET}_{i}$ is the original evapotranspiration in source grid cell $i$ which is located in the domain $\Omega_{1}$, and $\mathrm{ET}^{\prime}$ is the corresponding evaporation of different land use types. This description is a first-order approximation implying that major wind patterns remain similar when land use change occurs and feedback mechanisms such as altered energy balance, surface roughness, and aerosols (Bonan, 2008; Mahmood et al., 2014) have not yet been triggered or are of minor importance (Bagley et al., 2014). Empirical evaporation measurements of different land uses in the Amazon were derived from Large-Scale Biosphere-Atmosphere Experiment (LBA-ECO) flux tower data (see Table 2) (Sakai et al., 2004). The LBA-ECO flux tower observation was established in 2000 in the Santarém region in the Brazilian Amazon. The field has been converted into different land uses including old-growth forest, selective logging, bare soil, pasture land, and rice cropping during the flux tower's operation period. The evaporation was estimated by the eddy covariance (EC) method, corrected by the nocturnal boundary layer budget method for night-time respiration underestimates, and validated by Acevedo et al. (2004).

Changes in the annual surface runoff regime by altered moisture recycling under land use change are investigated 
Table 2. LBA-ECO evaporation data.

\begin{tabular}{lcccc}
\hline Land use type & $\begin{array}{c}\text { Bare } \\
\text { soil }\end{array}$ & $\begin{array}{c}\text { Dry } \\
\text { pastureland }\end{array}$ & $\begin{array}{c}\text { Wet } \\
\text { pastureland }\end{array}$ & $\begin{array}{c}\text { Rice } \\
\text { cropping }\end{array}$ \\
\hline Evaporation rate $\left(\mathrm{mm} \mathrm{day}^{-1}\right)$ & $1.2 \pm 0.7$ & $1.9 \pm 0.6$ & $2.2 \pm 0.9$ & $2.7 \pm 1.2$ \\
\hline
\end{tabular}

Indicated uncertainties are standard errors.

as well. By assuming that $\mathrm{ET}$ and $P$ are in equilibrium (i.e. mean annual evapotranspiration does not exceed mean annual precipitation) and steady groundwater storages, we use precipitation minus evaporation $(P-\mathrm{ET})$ to estimate annual surface runoff. We calculate the control state of $P-$ ET throughout catchments using the 10-year average of the respective input data from the MOD experiment (2000-2010). The $P-$ ET changes under different land use scenarios are obtained by calculating the altered precipitation in the catchment grid cells and subtracting altered evaporation $\left(\mathrm{ET}^{\prime}\right)$ according to each land use scenario. The $P-$ ET values under different land use scenarios are then compared with the control state.

\subsection{Sensitive pairs of sink and source regions}

High precipitation sensitivity of a sink region regarding land use changes in its source regions combines two aspects: firstly, the precipitation in the sink region must depend strongly on aerial moisture transport from terrestrial sources (i.e. high dependency on the aerial rivers) and secondly, the areal extent of the relevant source regions has to be rather small. The latter results in strong effects with even spatially limited land use changes. Given the importance of the Amazonian provision of moisture on the regional climate, we first calculate the precipitation recycled from the basin for each continental grid element. In the following, we identify the grid elements with the highest ratios (defined by the $98 \%$ percentile) of precipitation contributed by the moisture from the Amazon basin as sensitive sink areas. Next we determine the MIP (40\% threshold MIP; see Sect. 2.1.3) for the sensitive sink areas to examine their precipitation sensitivity to Amazonian land use changes.

\section{Results}

\subsection{Sensitive sinks and influential sources: water regime shifts by upwind land use change}

The most sensitive sinks regarding the evapotranspiration of the Amazon basin are situated in the eastern foothills of the Andes, a geographical region in southern Peru and western Bolivia, where over $70 \%$ of the precipitation originates from the Amazon, according to our results. The sensitivity to potential Amazonian land use change is shown in Fig. 2. The sensitivity increases westward throughout the Amazon for-

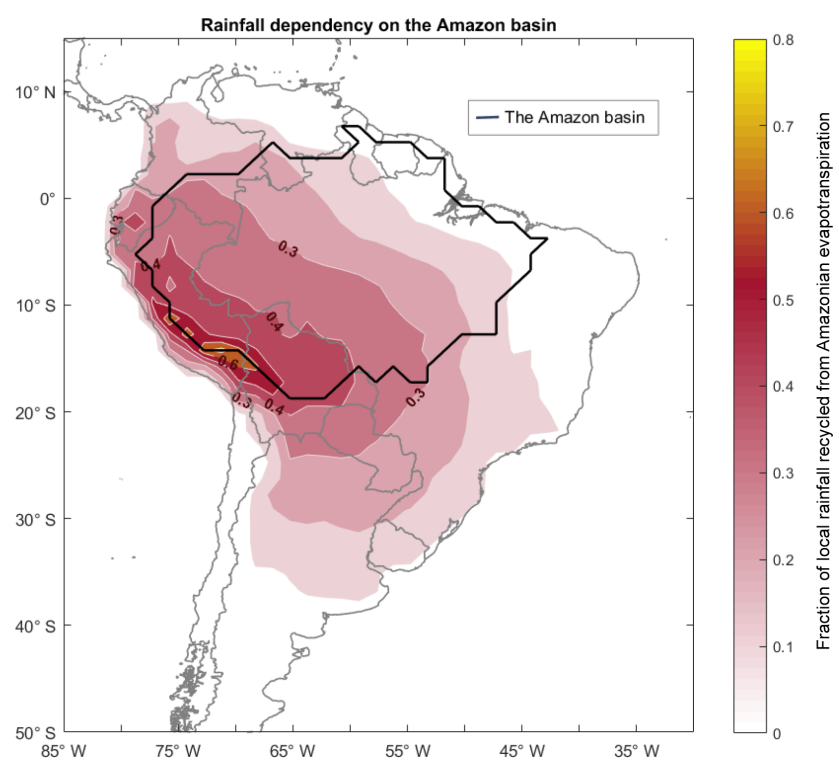

Figure 2. Rainfall dependency on the Amazon basin. The number shows the fraction of local rainfall recycled from Amazonian evapotranspiration. The yellow areas are among those regions having the greatest sensitivity to Amazonian land use change.

est and reaches its peak at its south-western fringe. We identified regions that have more than $50 \%$ of rainfall coming from Amazonian evapotranspiration $(98 \%$ percentile of the highest sensitivity to Amazonian land use change, hereafter called "sensitive areas") and tracked back the location of the most influential sources for them as the second step in the procedure described in Sect. 2.3. It turns out that the southwestern part of the Amazon forest exerts the strongest influence. As demonstrated by Fig. 3, the most influential precipitationshed (MIP; the area delimited by the first contour line in Fig. 3) of the sensitive areas is located in the region of Ucayali, Peru. This particular part of the Amazon forest governs the rainfall of the sensitive areas with high spatial efficiency (high control per unit area) compared to the rest of the moisture sources. While covering $3.5 \%$ of Amazonia, the MIP accounts for $50 \%$ of the Amazonian evapotranspiration's contribution ( $80 \%$ ) to the sensitive areas' continentally sourced rainfall.

The above result on the most sensitive source and sink regions leads to the choice of interesting areas to quantify the influence of defined land use scenarios on precipitation and 
Table 3. Estimated changes in annual rainfall $(\Delta P)$ and runoff $(\Delta R)$ over the Ucayali River basin outlet following land use scenarios in different spatial domains.

\begin{tabular}{|c|c|c|c|c|c|c|}
\hline \multirow{2}{*}{$\begin{array}{l}\text { Land use change domain } \\
\text { Ucayali River outlet's water regime }\end{array}$} & \multicolumn{2}{|c|}{ Ucayali basin } & \multicolumn{2}{|c|}{$\begin{array}{l}\text { MIP of Ucayali } \\
\text { river outlet }\end{array}$} & \multicolumn{2}{|c|}{$\begin{array}{c}\text { MIP of the river } \\
\text { basin excluding the } \\
\text { Ucayali basin } \\
\end{array}$} \\
\hline & $\Delta P$ & $\Delta R$ & $\Delta P$ & $\Delta R$ & $\Delta P$ & $\Delta R$ \\
\hline Bare soil & $-3 \%$ & $+103 \%$ & $-12 \%$ & $-9 \%$ & $-16 \%$ & $-50 \%$ \\
\hline Dry pastureland & $-2 \%$ & $+67 \%$ & $-8 \%$ & $-7 \%$ & $-12 \%$ & $-36 \%$ \\
\hline Wet pastureland & $-2 \%$ & $+52 \%$ & $-7 \%$ & $-6 \%$ & $-10 \%$ & $-30 \%$ \\
\hline Rice cropping & $-1 \%$ & $+27 \%$ & $-5 \%$ & $-4 \%$ & $-7 \%$ & $-19 \%$ \\
\hline
\end{tabular}

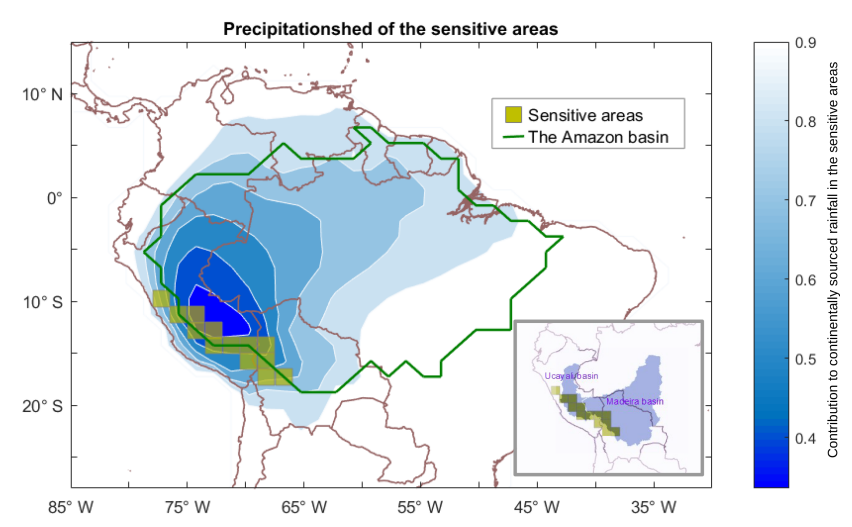

Figure 3. The precipitationshed of the sensitive areas. The contour value stands for the fraction of rainfall from continental evapotranspiration in sensitive areas that is evapotranspirated from the delimited region collectively. The first contour delimits areas (shown in dark blue) corresponding to the most influential precipitationshed (MIP) for the sensitive regions (represented by yellow cells). A total of $74.7 \%$ of the sensitive areas' total rainfall comes from continental evapotranspiration. Of this, $40 \%$ originates from the MIP.

runoff regimes. As we are interested in the relationship of land use effects with both precipitation and surface runoff availability, we investigate them at the outlet of the Ucayali River basin (referred to as the target sink hereafter), a sub-basin where half of the sensitive areas are located (see Fig. 3). Accordingly, we applied land use scenarios in different spatial domains including the Ucayali River basin (the watershed of the target sink) and the MIP of the target sink. In addition, land use scenarios are also employed to the MIP of the Ucayali River basin (the MIP of the watershed) but excluding the basin component cells in order to understand land use change influences outside of the watershed boundary, which is traditionally not covered in depth in water availability studies. Figure 4 shows the location of different land use scenario domains.

Different land use scenarios including the conversion of the areas to bare soil, dry and wet pastureland, and rice cropping are applied in each domain depicted in Fig. 4. For each domain and each scenario, we investigate changes in the rain-

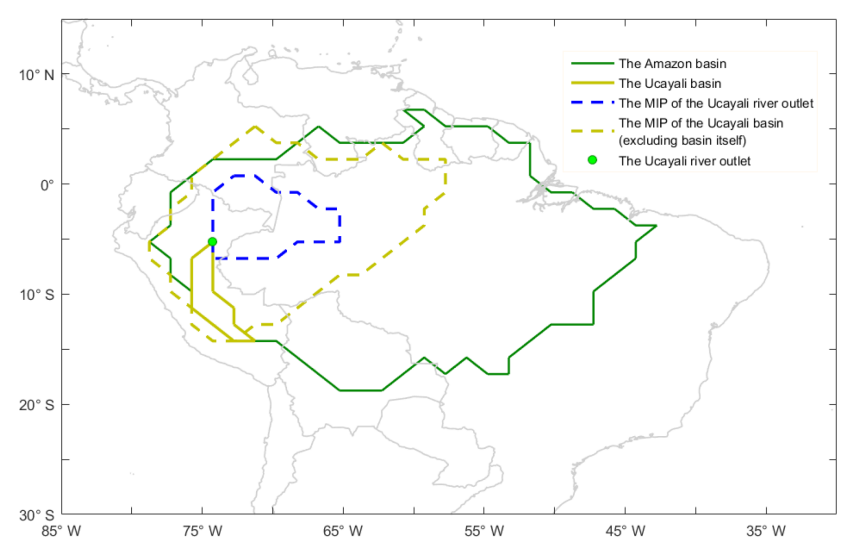

Figure 4. Different land use scenario domains for exploring rainfall and runoff susceptibility of the target sink (Ucayali River outlet). These domains include the Ucayali River basin (the watershed of the target sink), the MIP of the target sink, and the MIP of the Ucayali River basin (the MIP of the watershed) but excluding the basin component cells, in order to understand land use change influences outside of the watershed boundary. In addition, land use scenarios are also applied in the domains of the Amazon basin and the Amazon basin without the Ucayali River basin for upper bound investigation.

fall and runoff reception of the Ucayali River outlet, the target sink, as described in Sect. 2.2. Figure 5 shows the interactions which are considered: changes in evapotranspiration when applying land use scenarios influence the rainfall downwind in both the target sink (here the Ucayali River basin outlet) and the target sink's upstream watershed (here the Ucayali basin) through moisture recycling (the light blue arrows in Fig. 5), thus altering the rainfall and runoff reception in the target sink. We note that the runoff changes measured in the target sink are also influenced by the land use scenario applied in the domain of the target sink's upstream watershed (here the Ucayali basin) as shown by the black arrows in Fig. 5.

Changes in the rainfall and runoff reception of the target sink vary in direction and magnitude when land use change occurs in different spatial domains (Table 3). The bare soil land use scenario leads to more considerable alteration than 
Table 4. Estimated changes in annual rainfall over different regions when applying various land use scenarios in the Amazon basin. Note that annual rainfall is reduced continental-wise, but the sensitive areas experience greater reductions.

\begin{tabular}{lccrrrr}
\hline & Area & Rainfall & \multicolumn{3}{c}{ Rainfall change for different land uses (\%) } \\
\cline { 4 - 7 } & $\left(\mathrm{km}^{2}\right)$ & $\begin{array}{c}\text { dependency } \\
\text { on the Amazon } \\
\text { basin }(\%)\end{array}$ & $\begin{array}{c}\text { Bare } \\
\text { soil }\end{array}$ & $\begin{array}{r}\text { Dry } \\
\text { pastureland }\end{array}$ & $\begin{array}{r}\text { Wet } \\
\text { pastureland }\end{array}$ & $\begin{array}{r}\text { Rice } \\
\text { cropping }\end{array}$ \\
& & 60.3 & -38.5 & -25.8 & -20.4 & -11.3 \\
Sensitive areas & $3.25 \times 10^{5}$ & 67.5 & -18.2 & -12.7 & -10.4 & -6.5 \\
Amazon basin & $7.77 \times 10^{6}$ & 27.5 & -12.9 & -8.8 & -7.0 & -4.0 \\
South American continent & $1.70 \times 10^{7}$ & 20.0 & -12.9 & & &
\end{tabular}

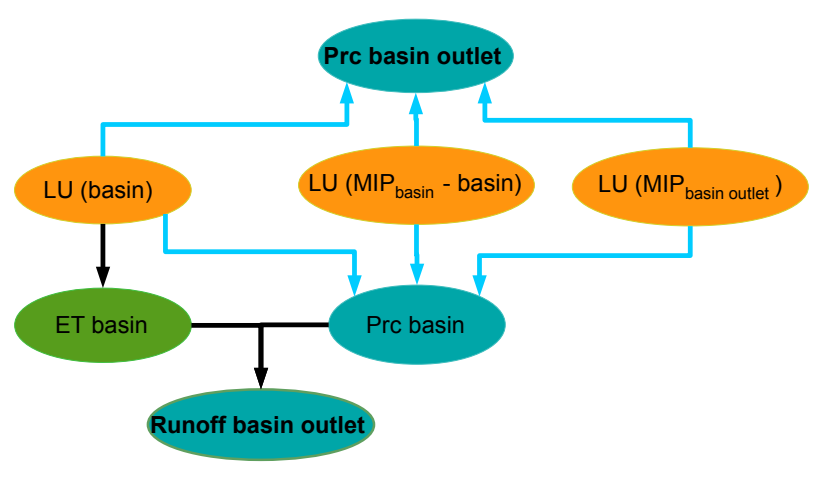

Figure 5. Influence of land use (LU) in different spatial domains (orange ellipses) on runoff and precipitation (cyan blue ellipses) of the outlet of the basin. Light blue arrows show influences via moisture recycling ("aerial rivers"); black arrows represent surfacebound relations. ET denotes the annual evapotranspiration of the basin and Prc stands for precipitation.

the pastureland and rice cropland scenarios, which have the least impact. Generally, the rainfall decreases when land use changes, but the extent depends on the location of such a change. Land use change in the MIP of the target sink leads to a reduction in the target sink's rainfall ranging from $5 \%$ (rice cropping) to $12 \%$ (bare soil). On the other hand, when land use change occurs in the Ucayali River basin, the rainfall in the target sink experiences a mild reduction of less than $5 \%$ in all scenarios. Runoff shifts differ in sign when land use change occurs in different locations. An increase in runoff received by the target sink is found when applying land use scenarios in the Ucayali basin: the runoff is intensified by adding a quarter ( $27 \%$, rice cropping) to more than doubling (103\%, bare soil) the original flow. However, we found that applying land use scenarios outside of the watershed boundary has negative influences on the runoff of the target sink. Land use change in the MIP of the watershed results in a $19 \%$ (rice cropping) to $50 \%$ (bare soil) reduction in the target sink's runoff. The heterogeneous hydrological response due to the location of land use change is discussed in Sect. 4.

\subsection{Upper bounds for the influences of Amazonian land use change}

So far we have investigated the most sensitive source-sink pairs and have chosen the considered land use change areas accordingly. However, land use change may occur in various parts of the Amazon basin. Therefore, we estimated rainfall and runoff changes considering land use change Amazonwide to describe the upper bounds of land use change impacts on water availability. For that, in the following we apply different hypothetical homogeneous land uses to the whole Amazon basin and calculate their effects on precipitation and runoff at different locations.

Table 4 shows the results for the reduction of rainfall in different Amazonian land use scenarios. Sensitive areas can experience 11.3-38.5\% (according to scenarios) annual rainfall reduction via moisture recycling when all of the Amazon forest is cultivated. The reduction in sensitive areas almost doubles the reduction of rainfall in the Amazon basin average (6.5-18.2\%, according to scenarios) and it also greatly surpasses the average South American continent decrease in rainfall (4.0-12.9\%, according to scenarios). The bare soil land use scenario results in the greatest reduction in rainfall while the rice cropping scenario exerts the least influence on rain reception in the sensitive areas. The same pattern appears in the continental and the Amazon basin average.

Conversely, runoff estimates rise in all land use scenarios but to a different extent across sub-basins. As shown in Table 5, the bare soil land use scenario introduces the greatest increase (by $32.7 \%$ ) among all scenarios in the runoff of the Ucayali River basin, a sub-basin where half of the sensitive areas are located. Rice cropping has a milder impact, resulting in nearly a $1 \%$ increase in the Ucayali runoff. The extent of the runoff increase is different across the basins. Runoff estimates of the Madeira basin, the largest sub-basin in the Amazon (see Fig. 3), increase in the range of $4.1 \%$ (rice cropping) to $40.3 \%$ (bare soil). The spatial pattern of $P$ - ET change in different Amazonian land use scenarios (bare soil, dry pastureland, wet pastureland, and rice cropping) can be seen in Fig. 6. As this figure shows, generally, land use scenarios for almost the entire Amazon basin result in a surface runoff increase across the Amazon basin but a 
Table 5. Runoff ( $P-$ ET) estimates in different regions under different land use scenarios.

\begin{tabular}{|c|c|c|c|c|c|c|}
\hline & & Control & $\begin{array}{r}\text { Bare } \\
\text { soil }\end{array}$ & $\begin{array}{r}\text { Dry } \\
\text { pastureland }\end{array}$ & $\begin{array}{r}\text { Wet } \\
\text { pastureland }\end{array}$ & $\begin{array}{r}\text { Rice } \\
\text { cropping }\end{array}$ \\
\hline $\begin{array}{l}\text { Ucayali basin } \\
\text { (3.1\% of the }\end{array}$ & $\begin{array}{l}P-\text { ET in the Ucayali basin } \\
\left(10 \mathrm{~km}^{3} \mathrm{yr}^{-1}\right)\end{array}$ & 23.285 & 30.891 & 27.444 & 25.966 & 23.504 \\
\hline Amazon) & $\begin{array}{l}\text { Comparison with the } \\
\text { control group }\end{array}$ & - & $+32.7 \%$ & $+17.9 \%$ & $+11.5 \%$ & $+0.9 \%$ \\
\hline $\begin{array}{l}\text { Madeira basin } \\
(13.9 \%\end{array}$ & $\begin{array}{l}P-\text { ET in the Madeira basin } \\
\left(10 \mathrm{~km}^{3} \mathrm{yr}^{-1}\right)\end{array}$ & 103.15 & 144.68 & 127.39 & 119.84 & 107.42 \\
\hline $\begin{array}{l}\text { of the } \\
\text { Amazon) }\end{array}$ & $\begin{array}{l}\text { Comparison with the } \\
\text { control group }\end{array}$ & - & $+40.3 \%$ & $+23.4 \%$ & $+16.2 \%$ & $+4.1 \%$ \\
\hline
\end{tabular}
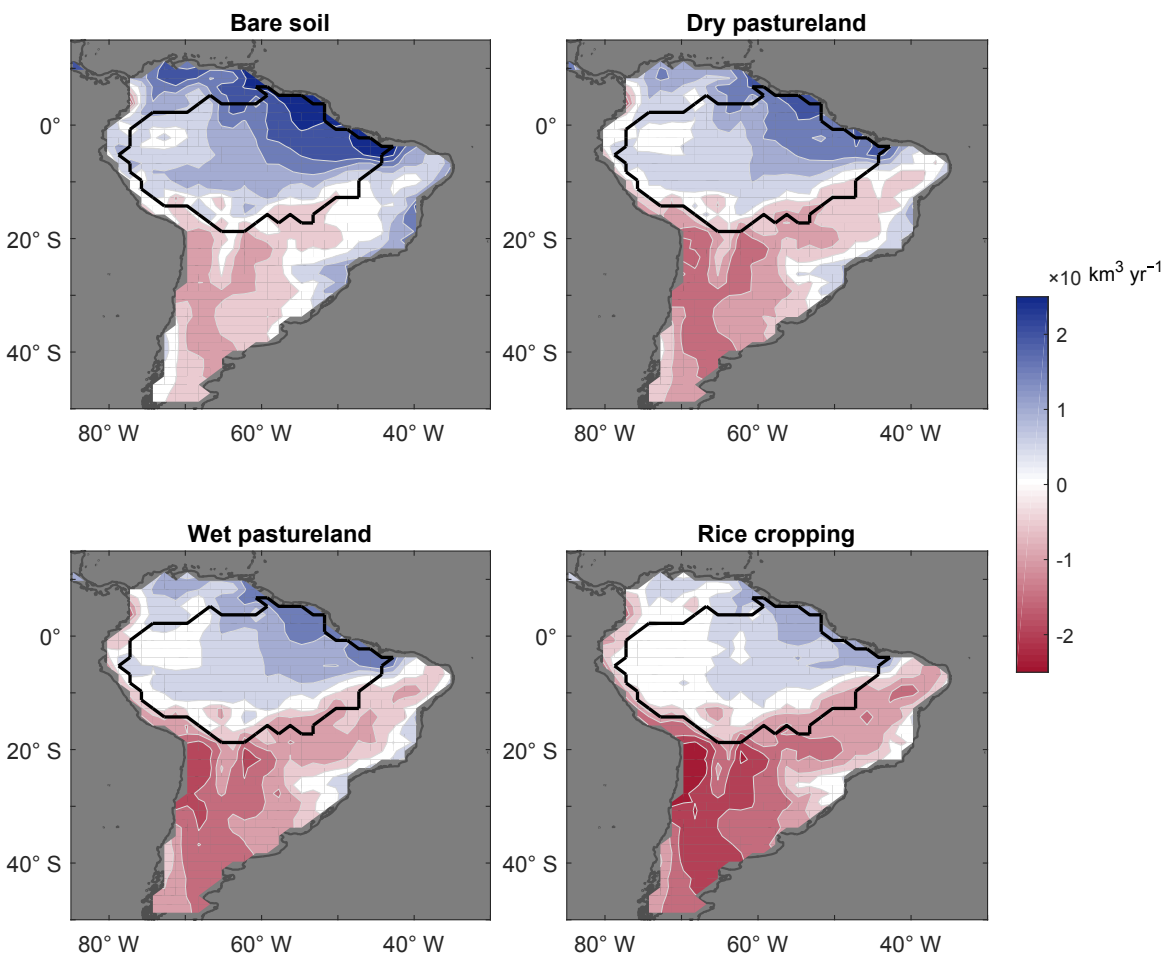

Figure 6. Spatial patterns in local runoff $(P-E T)$ changes compared to the control state for land use scenarios applied in the Amazon basin. Runoff generally increases in all scenarios (especially in the north-eastern part of the Amazon basin) but the rise is less pronounced in the rice cropping scenario over Amazonia.

decrease outside of it. Runoff increase within the Amazon basin also shows spatial differences as it is more pronounced in the north-eastern part of the Amazon and less significant in the western part.

Similarly to in our investigation on smaller domains such as the MIP of the target sink, we apply different land use scenarios in the domains of Amazon basin and the Amazon basin without the Ucayali River basin to investigate the upper bounds of the rainfall and runoff reception changes in the target sink, the Ucayali River basin outlet (see Table 6). The comparison of these upper bounds with the impacts from the influential sources hotspots is presented in Sect. 4.3. Rain- fall in the target sink decreases in the range of $10 \%$ (rice cropping) to $26 \%$ (bare soil) in all cultivated Amazon basin scenarios, but runoff in the target sink increases by $11 \%$ (wet pastureland) to $33 \%$ (bare soil). Converting the whole Amazon basin into rice cropping has in fact a very small influence on the runoff received by the target sink $(-1 \%)$. Contrary to the results from applying scenarios to the Amazon basin, runoff decreases in the range of $27 \%$ (rice cropping) to $69 \%$ (bare soil) when applying land use scenarios in the domain of the Amazon basin without the Ucayali River basin. This resonates with the findings in Sect. 3.1 that applying land use scenarios outside of the watershed boundary has negative in- 
fluences on the runoff of the target sink and is discussed in the following section.

\section{Discussion}

\subsection{Sensitive sinks under pressure}

The sensitive areas most dependent on the moisture recycled from the Amazon forest have been identified as being situated in the Peruvian Amazon and its transition to the Andes, such as the Junín, Cusco, and Puno regions, and a part of western Bolivia. Given that the average annual rainfall of the sensitive areas is $997 \mathrm{~mm} \mathrm{yr}^{-1}$ (on average $74.7 \%$ from terrestrial recycling), the $11.3-38.5 \%$ rainfall reduction from the upper bound of our investigation has considerable impacts on the ecosystems and agriculture in these areas, especially during dry seasons (Bagley et al., 2014; Alves et al., 2017). Though this upper limit in which land use change takes place in the whole Amazon is hypothetical, land use change within the MIP, covering $3.5 \%$ of the Amazon, is possible (Aguiar et al., 2016). As it controls half the Amazonian provision of evapotranspiration in the sensitive areas, the land use change taking place in the MIP has a greater ability to alter the rainfall of the sensitive regions compared with that which occurs in the rest of the Amazon basin. The location of the MIP for the sensitive areas is identified here in the Ucayali and Madre de Dios region of Peru, as shown in Fig. 3. About $2.76 \%$ of the forests were cleared in the Ucayali region in the period between 2001 and 2014 (MINAM, 2017) but the deforestation rate is expected to increase because of continuing migration into these regions and increasing investment in roads and transportation (Piu and Menton, 2014).

Our results on the spatial pattern of rainfall dependency in the Amazon basin (Fig. 2) agree with maps produced in studies on other aspects of moisture recycling (Eltahir and Bras, 1994, Figs. 4 and 6; Burde et al., 2006), though the rainfall dependency may be slightly overestimated along the Andes because of the imbalance between the input precipitation TRMM product and the evapotranspiration product MOD16ET (Zemp et al., 2014). Nevertheless, the overestimation is small when the MOD experiment reports general agreement with other studies using other datasets and other moisture tracking approaches (see Table 2; Zemp et al., 2014).

\subsection{Interconnected aerial and surface rivers - spatially different response to land use change}

Our investigation suggests that the sensitive areas' rainfall reacts more significantly to land use change in the Amazon basin, by doubling the average rainfall reduction of the Amazon basin and tripling that of the South American continent average, and this propagates to the runoff responses in the sensitive areas. Taking the upper bound investigation for instance, significant drops in evapotranspiration due to land use scenarios applied within the Amazon basin lead to higher runoff estimates ( $P-$ ET surpluses) throughout the basin. However, these runoff rises are more compensated for in sensitive catchments which experience more significant rainfall reduction by land use change. This is reflected in the spatial heterogeneity in the extent of runoff response across basins (Fig. 6; also see Table 5 for the comparison between the Ucayali River basin and the Madeira River basin runoff responses). As shown in Fig. 6, the rise in $P-$ ET in each scenario becomes less prominent towards the western Amazon, corresponding to growing sensitivity of the rainfall to Amazonian land use change (see Fig. 2). The north-eastern part of the Amazon, where rainfall is the least dependent on Amazonian evapotranspiration, shows the greatest growth in the $P-$ ET surplus in all scenarios.

We estimated altered rainfall as a result of land use change through the moisture recycling process while neglecting the moisture pathway dynamic resulting from the altered energy balance (Shukla et al., 1990; Bonan, 2008; Mahmood et al., 2014; Lejeune et al., 2015), the deepening convective boundary layer (Fisch et al., 2004), and the reduction in surface roughness (Khanna and Medvigy, 2014) after land use change. Nevertheless, our estimate of shifts in rainfall caused by land use change is in line with results from studies considering such effects. Our calculation of an annual rainfall reduction of $10.4-12.7 \%$ in both wet and dry pastureland Amazon scenarios falls in the range of a mean $16.5 \pm 13 \%$ reduction in annual rainfall in the Amazon basin, reported from 44 global general circulation model (GCM) and regional climate model (RCM) studies that hypothetically convert $100 \%$ of the Amazon into soybean or pastureland use in Spracken and Garcia-Carreras's (2015) meta-analysis. A total of 18 out of the 44 studies also considered roughness and albedo changes through coupled runs with land surface models or biosphere models. Our estimates are still in agreement with their results, reporting an average $15.3 \pm 8 \%$ reduction in annual Amazon rainfall (Spracklen and Garcia-Carreras, 2015). In this case, the neglected processes have minor influences on our overall results.

As for runoff discharges, modelling outputs from previous studies applying Amazon deforestation scenarios have diverse predictions. Some report increases after land use change (Dirmeyer and Shukla, 1994; Lean and Rowntree, 1997; Kleidon and Heimann, 2000) and some found a decrease (Henderson-Sellers et al., 1993; Hahmann and Dickinson, 1997; Voldoire and Royer, 2004). Our results show that runoff response differs from basin to basin and depends on alternative land use practices. This spatial heterogeneity in the $P-$ ET response (as shown in Fig. 6) may contribute to the diversity of the findings from previous studies. 
Table 6. Estimated changes in annual rainfall $(\Delta P)$ and runoff $(\Delta R)$ over the Ucayali River basin outlet following land use scenarios in the Amazon basin and the Amazon basin excluding the Ucayali basin.

\begin{tabular}{|c|c|c|c|c|}
\hline \multirow{2}{*}{$\begin{array}{l}\text { Land use change domain } \\
\text { Ucayali River outlet's water regime }\end{array}$} & \multicolumn{2}{|c|}{$\begin{array}{l}\text { Amazon basin excluding } \\
\text { the Ucayali basin }\end{array}$} & \multicolumn{2}{|c|}{ Amazon basin } \\
\hline & $\Delta P$ & $\Delta R$ & $\Delta P$ & $\Delta R$ \\
\hline Bare soil & $-23 \%$ & $-69 \%$ & $-26 \%$ & $+33 \%$ \\
\hline Dry pastureland & $-17 \%$ & $-49 \%$ & $-19 \%$ & $+18 \%$ \\
\hline Wet pastureland & $-14 \%$ & $-41 \%$ & $-16 \%$ & $+11 \%$ \\
\hline Rice cropping & $-9 \%$ & $-27 \%$ & $-10 \%$ & $-1 \%$ \\
\hline
\end{tabular}

\subsection{Water conservation hotspots outside of watersheds}

Our results suggest that a given region's water availability is not only related to land activities in its upstream watershed but is also highly controlled by those in its MIP and its watershed's MIP. These are the areas not necessarily located in the upstream watershed, which is traditionally considered in land use assessments for water conservation.

The importance of land use change in the MIP on the target sink's rainfall is shown by comparing it with impacts on rainfall by land use change in the whole Amazon (the upper bound investigation in Sect. 3.2). In our exploration for the Ucayali River basin outlet as a target sink, land use change in its MIP results in a 5-12\% drop of the target sink's rainfall. This is considerable compared with a $10-26 \%$ decrease in the target sink's rainfall by land use change in the whole Amazon basin, 9 times the size of the target sink's MIP. In contrast, when land use change occurs in the Ucayali River basin, the reduction in the target sink's rainfall is considerably lower (by less than $5 \%$ ).

The interconnection between surface rivers and aerial rivers implies that the land use changes taking place outside of the watershed can be crucial to the runoff reception, as also found in Wang-Erlandsson et al.'s (2017) global analysis. In fact, in our investigation, land use change that happens in the target sink's upstream watershed brings converse impacts on runoff compared with land use change taking place outside of the target sink's upstream watershed. We found an abundant increase in the runoff received in the Ucayali River outlet, the target sink, when land use scenarios are applied in the Ucayali basin. This is consistent with modelling and observational studies that investigate runoff response to land use change in a specific sub-basin or catchment (Costa et al., 2003; Coe et al., 2011; Panday et al., 2015). However, the runoff reduces by $27-69 \%$ when employing land use scenarios in the domain of the Amazon basin excluding the Ucayali River basin (see Table 6). Within this area, land use change in the MIP of the watershed is more influential on the target sink's runoff. The result is a $19-50 \%$ reduction, even though its areal content is less than half that of the Amazon basin excluding the Ucayali basin. These results also reflect that when applying land use scenarios at a pan-Amazon scale, runoff estimates of a specific watershed yield contradicting responses to land use change in different moisture source areas (within the watershed a positive response, outside of the watershed a negative response).

\subsection{Managing interconnected surface and aerial rivers crossing boundaries}

Our results suggest that sensitive sinks (e.g. the sensitive areas; see Sect. 3.1) and influential sources such as the MIP of the given region and the MIP of its watershed are the areas crucial for managing water availability under interconnected aerial and surface river regimes. In order to do this, transboundary involvement crossing regions, municipalities, provinces, or countries is necessary. For example, our results of the sensitive pairs reflect that as they are located in the downstream area of the aerial river, the Bolivian sensitive areas should recognize the importance of the land activities in the neighbouring Peruvian Amazon. For another example of the target sink in the Ucayali basin outlet, though its watershed area is located completely in Peru, its MIP has Peruvian, Brazilian, and Colombian components. Therefore, for the Amazon countries' sustainable use and management of the fresh water, understanding the roles in the aerial river regime within and across individual countries and initiation of co-management are crucial. Previously, Dirmeyer et al. (2009) have investigated the imports and exports of the moisture per country globally. Though these moisture budgets can be useful for understanding each country's dependency, they provide limited spatial information for conservation targets. Keys et al. (2012) introduced the concept of precipitationsheds to identify areas providing moisture for precipitation in downwind areas. We extended the discussion on precipitationshed boundaries (Keys et al., 2014, 2017) by showing that a particular component of the precipitationshed with small areal extent can be especially influential (MIP) for rainfall and that the interlinkage between the aerial and surface rivers marks the importance of the MIP of the watershed for runoff. The identification of such hotspots and quantification of potential hydrological influences by land use change within them provide conservation targets for the 
sustainable management of interconnected surface and aerial river regimes crossing boundaries.

\subsection{Limitations}

Our analysis based on the average output of the period 20002010 from the MOD experiment has not accounted for the interannual variation of moisture recycling, though it is generally reported as small in the Amazon basin (Bosivolich and Chern, 2006). However, we note that the two major droughts (2005 and 2010) in the simulated period of the MOD experiment may lead to an overestimation of the moisture recycling influence (Bagley et al., 2014). The seasonal variation was also masked despite the slight difference (3-5\%) reported by Zemp et al. (2014) between dry and wet seasons in the precipitation recycling ratio in Amazonia over the investigation period. We are aware that the spatial patterns of recycling vary through the seasons (Arraut et al., 2012; Zemp et al., 2014) and that this can influence the identification of the MIP location. However, Keys et al. (2014) concluded that the core part of precipitationsheds can be suggestive for the analysis of terrestrial precipitation recycling, which may be reflected by our decadal average results. Still, further studies that focus on seasonal specific purposes such as rain-fed agriculture should take the growing season's precipitationshed shift into account.

Other uncertainties could remain in the extrapolation of LBA-ECO flux tower data measured in the Santarém region for the entire Amazon basin. The spatial variability in evapotranspiration that might arise from varying environmental conditions (Fisher et al., 2008) is not considered. However, the evapotranspiration approximation is still site- and ecoregion-based (Christoffersen et al., 2014), while the evapotranspiration modelling power over Amazon forest ecosystems is still poor (Karam and Bras, 2008; Werth and Avissar, 2004; Maeda et al., 2017). A similar limitation is shown in our estimation of surface runoff. Our assumption of steady groundwater storage is restrained by the fact that a lack of adequate soil hydraulic information (Miguez-Macho and Fan, 2012) leads to a modelling challenge of groundwater dynamics across the Amazon basin in addition to the lack of groundwater observation data due to remoteness. The development of remote monitoring tools such as the Gravity Recovery And Climate Experiment (GRACE) satellite mission (Tapley, 2004) allows the examination of the terrestrial water storage (TWS) and can be potentially used for estimating groundwater storage (Rodell and Famiglietti, 2002). However, the groundwater storage's importance in regulating the TWS change still remains inconclusive in the Amazon basin. While some studies found river water storage to explain most of the TWS variation (Kim et al., 2009), some others found groundwater storage dominance (Niu et al., 2007; Pokhrel et al., 2013) or the equal importance of both (Alkama et al., 2010) in contributing to TWS changes due to process representation differences in the models.
In the present study, we focus on the effect of land use change on moisture availability through the moisture recycling process. Other processes are also known to be involved in shifting water regime when land use change occurs, for example, rising aerosols modifying cloud microphysics (Koren et al., 2012), altered infiltration and hydraulic redistribution (Lee et al., 2005; Yeh and Famiglietti, 2009), changed surface roughness (Khanna and Medvigy, 2014; Khanna et al., 2017), and its forcing on convective systems (Baidya Roy and Avissar, 2000; Baidya Roy, 2002; D'Almeida et al., 2006). Feedback mechanisms such as vegetation-atmosphere interaction intensifying droughts and driving large forest dieback (Nepstad et al., 2008; Malhi et al., 2009; Zemp et al., 2017a, b) can also influence the rainfall and runoff regime. Since our study has suggested the sensitive sinks and influential sources' importance for calculating the shifts in water regime, further studies on how these processes interact with moisture recycling spatial heterogeneity can further advance our insights into the water regime shifts caused by land use change.

\section{Conclusion and outlook}

From our analysis of the moisture recycling process, we conclude that the impacts of Amazonian land use change on the water regime have spatial heterogeneity in two ways. First, hydrological responses in moisture sinks vary spatially. Second, land use change in different locations exerts varying influences. This spatial difference implies sensitive sinks and influential sources where land use change could have strong downwind impacts on water availability. Using a moisture tracking experiment of a water balance model (WAM-2layers), we have identified the areas sensitive to Amazonian land use change in the area of semi-arid southern Peru and eastern Bolivia. We quantified changes in rainfall and runoff by various land use scenarios in the Amazon and found that sensitive areas experience a more significant rainfall reduction (11.3-38.5\%, depending on scenarios) and a lower runoff increase $(0.9-32.7 \%$ in the Ucayali River, depending on scenarios). In addition, we add to recent discussions on precipitationshed boundaries by introducing the concept of MIPs (most influential precipitationsheds), where the most important source areas of moisture for a given region are collectively situated (within a relatively small area) and backtracked the MIP of the sensitive areas, which is located in the Ucayali and Madre de Dios region in the Peruvian Amazon. We further explored the varying influences of land use change on a target sink's water availability from different source areas and found that land use change in the upstream watershed of the target sink leads to a runoff rise, while land use change occurring outside of the target sink's upstream watershed leads to a reduction in runoff. We also identified the MIP of the target sink's upstream watershed as the hotspot for conserving runoff (19-50\% reduction, de- 
pending on scenarios) and the MIP of the target sink as the hotspot for conserving rainfall (5-12\% reduction, depending on scenarios) for land use assessment. Our results also show that the $40 \%$ threshold MIP utilized in the present study is plausible in reflecting important regions of moisture contribution to a given sink. However, the MIP threshold for further studies should be decided depending on different study purposes, tools, and focus regions.

The importance of spatially different land use change impacts on the water regime found in our analysis can explain the diversity of other modelling experiments' findings. Macro-scale experiments reflect aggregated influences and responses from different spatial components; thus they do not contradict different findings from mesoscale experiments, in which estimates are geographically specific. Nevertheless, for conservation targets, these aggregated results are rarely suggestive. For future meso-scale analysis, we suggest a shift of spatial focus from a pure watershed study because land use changes outside of a target area's watershed can also be very influential. Our results also reflect that the deforestation tipping point, beyond which rainfall changes will lead to strong rainfall reductions with drastic ecological impact on the forest (Lawrence and Vandecar, 2015; Zemp et al., 2017b), can be lower when the deforestation takes place in influential source areas, such as MIPs.

At a national level, we suggest that a crucial step towards the Amazon countries' sustainable usage of water (resonating the fulfilment of SDGs 6 and 15) is to include the influence of land activity in water management. However, as opposed to only traditionally recognizing upstream watershed regions in water management, land use in the precipitationsheds, especially the MIPs, is of importance in both the rainfall and runoff regime sustaining the ecosystem (Coe et al., 2013) and agriculture (Bagley et al., 2012; Keys et al., 2014). Our results also highlight the importance of transboundary cooperation along both the surface and the aerial river for managing water regime shift caused by land use change. Topdown international laws and regulation offer an opportunity (Keys et al., 2017) but bottom-up national efforts should focus on understanding each country's role in the aerial river regime crossing boundaries and the places in need of action. This can be done by recognizing the moisture sinks sensitive to land use change and locating influential sources (MIPs) that exert strong controls on the rainfall and runoff regime and water availability of the sensitive regions, as demonstrated in the present study.

Code availability. The WAM-2layers model code is available at https://github.com/ruudvdent/WAM2layersPython under the GNU General Public License.
Data availability. The LBA-ECO flux tower data are available online at https://daac.ornl.gov/cgi-bin/dataset_lister.pl?p=11\T1\ textbackslash\#surf_hydro_and_water_chem_anchor and in Sakai et al. (2004).

Competing interests. The authors declare that they have no conflict of interest.

Acknowledgements. This research was supported by the German International Climate Protection Initiative (project: Sustainable Latin America, reference number 42206-6157). Delphine C. Zemp acknowledges funding from the DFG (project IRT1740). We sincerely thank both referees, Patrick W. Keys and Rogier S. Westerhoff, for constructive comments that helped to improve the manuscript. We are grateful to Florian Gollnow, Stefanie L. Becker, and David M. Landholm Haight for their comments on an earlier version of this manuscript. We also thank Ruud van der Ent, Kirsten Thonicke, and Anja Rammig for discussions on the WAM-2layers used in this study.

The article processing charges for this open-access publication were covered by the Potsdam Institute for Climate Impact Research (PIK).

Edited by: Alexander Gelfan

Reviewed by: Patrick Keys and Rogier Westerhoff

\section{References}

Acevedo, O. C., Moraes, O. L., Da Silva, R., Fitzjarrald, D. R., Sakai, R. K., Staebler, R. M., and Czikowsky, M. J.: Inferring nocturnal surface fluxes from vertical profiles of scalars in an Amazon pasture, Global Change Biol., 10, 886-894, https://doi.org/10.1111/j.1529-8817.2003.00755.x, 2004.

Aguiar, A. P. D., Vieira, I. C. G., Assis, T. O., Dalla-Nora, E. L., Toledo, P. M., Santos Junior, R. A. O., Batistella, M., Coelho, A. S., Savaget, E. K., Aragão, L. E. O. C., Nobre, C. A., and Ometto, J. P. H.: Land use change emission scenarios: anticipating a forest transition process in the Brazilian Amazon, Global Change Biol., 22, 1821-1840, https://doi.org/10.1111/gcb.13134, 2016.

Alkama, R., Decharme, B., Douville, H., Becker, M., Cazenave, A., Sheffield, J., Voldoire, A., Tyteca, S., and Le Moigne, P.: Global Evaluation of the ISBA-TRIP Continental Hydrological System. Part I: Comparison to GRACE Terrestrial Water Storage Estimates and In Situ River Discharges, J. Hydrometeorol., 11, 583600, https://doi.org/10.1175/2010JHM1211.1, 2010.

Alves, L. M., Marengo, J. A., Fu, R., and Bombardi, R. J.: Sensitivity of Amazon Regional Climate to Deforestation, Am. J. Clim. Change, 6, 75-98, https://doi.org/10.4236/ajcc.2017.61005, 2017.

Anderson-Teixeira, K. J., Snyder, P. K., Twine, T. E., Cuadra, S. V., Costa, M. H., and DeLucia, E. H.: Climate-regulation services of natural and agricultural ecoregions of the Americas, Nat. Clim. Change, 2, 177-181, https://doi.org/10.1038/nclimate1346, 2012. 
Aragão, L., Poulter, B., Barlow, J. B., Anderson, L. O., Malhi, Y., Saatchi, S., Phillips, O. L., and Gloor, E.: Environmental change and the carbon balance of Amazonian forests, Biol. Rev., 89, 913-931, https://doi.org/10.1111/brv.12088, 2014.

Arraut, J. M., Nobre, C., Barbosa, H. M. J., Obregon, G., and Marengo, J.: Aerial rivers and lakes: Looking at large-scale moisture transport and its relation to Amazonia and to subtropical rainfall in South America, J. Climate, 25, 543-556, https://doi.org/10.1175/2011JCLI4189.1, 2012.

Awadallah, A. G. and Awadallah, N. A.: A Novel Approach for the Joint Use of Rainfall Monthly and Daily Ground Station Data with TRMM Data to Generate IDF Estimates in a Poorly Gauged Arid Region, Open J. Mod. Hydrol., 3, 1-7, https://doi.org/10.4236/ojmh.2013.31001, 2013.

Badger, A. M. and Dirmeyer, P. A.: Climate response to Amazon forest replacement by heterogeneous crop cover, Hydrol. Earth Syst. Sci., 19, 4547-4557, https://doi.org/10.5194/hess-19-45472015, 2015.

Bagley, J. E., Desai, A. R., Dirmeyer, P. A., and Foley, J. A.: Effects of land cover change on moisture availability and potential crop yield in the world's breadbaskets, Environ. Res. Lett., 7, 014009 , https://doi.org/10.1088/1748-9326/7/1/014009, 2012.

Bagley, J. E., Desai, A. R., Harding, K. J., Snyder, P. K., and Foley, J. A.: Drought and deforestation: Has land cover change influenced recent precipitation extremes in the Amazon?, J. Climate, 27, 345-361, https://doi.org/10.1175/JCLI-D-12-00369.1, 2014.

Baidya Roy, S.: Impact of land use/land cover change on regional hydrometeorology in Amazonia, J. Geophys. Res., 107, 8037, https://doi.org/10.1029/2000JD000266, 2002.

Baidya Roy, S. and Avissar, R.: Scales of response of the convective boundary layer to land-surface heterogeneity, Geophys. Res. Lett., 27, 533-536, https://doi.org/10.1029/1999GL010971, 2000.

Barona, E., Ramankutty, N., Hyman, G., and Coomes, O. T.: The role of pasture and soybean in deforestation of the Brazilian Amazon, Environ. Res. Lett., 5, 024002, https://doi.org/10.1088/1748-9326/5/2/024002, 2010.

Bonan, G. B.: Forests and Climate Change: Forcings, Feedbacks, and the Climate Benefits of Forests, Science, 320, 1444-1449, https://doi.org/10.1126/science.1155121, 2008.

Bosilovich, M. G. and Chern, J.-D.: Simulation of Water Sources and Precipitation Recycling for the MacKenzie, Mississippi, and Amazon River Basins, J. Hydrometeorol., 7, 312-329, https://doi.org/10.1175/JHM501.1, 2006.

Brubaker, K. L., Entekhabi, D., and Eagleson, P. S.: Estimation of continental precipitation recycling, J. Climate, 6, 1077-1089, https://doi.org/10.1175/15200442(1993)006<1077:EOCPR>2.0.CO;2, 1993.

Burde, G. I., Gandush, C., and Bayarjargal, Y.: Bulk recycling models with incomplete vertical mixing. Part II: Precipitation recycling in the Amazon basin, J. Climate, 19, 1473-1489, https://doi.org/10.1175/JCLI3688.1, 2006.

Chapin, F. S., Randerson, J. T., McGuire, A. D., Foley, J. A., and Field, C. B.: Changing feedbacks in the climatebiosphere system, Front. Ecol. Environ., 6, 313-320, https://doi.org/10.1890/080005, 2008.

Christoffersen, B. O., Restrepo-Coupe, N., Arain, M. A., Baker, I. T., Cestaro, B. P., Ciais, P., Fisher, J. B., Galbraith, D., Guan, X., Gulden, L., van den Hurk, B., Ichii, K., Imbuzeiro, H.,
Jain, A., Levine, N., Miguez-Macho, G., Poulter, B., Roberti, D. R., Sakaguchi, K., Sahoo, A., Schaefer, K., Shi, M., Verbeeck, H., Yang, Z. L., Araújo, A. C., Kruijt, B., Manzi, A. O., da Rocha, H. R., von Randow, C., Muza, M. N., Borak, J., Costa, M. H., Gonçalves de Gonçalves, L. G., Zeng, X., and Saleska, S. R.: Mechanisms of water supply and vegetation demand govern the seasonality and magnitude of evapotranspiration in Amazonia and Cerrado, Agr. Forest Meteorol., 191, 3350, https://doi.org/10.1016/j.agrformet.2014.02.008, 2014.

Cleugh, H. A., Leuning, R., Mu, Q., and Running, S. W.: Regional evaporation estimates from flux tower and MODIS satellite data, Remote Sens. Environ., 106, 285-304, https://doi.org/10.1016/j.rse.2006.07.007, 2007.

Coe, M. T., Latrubesse, E. M., Ferreira, M. E., and Amsler, M. L.: The effects of deforestation and climate variability on the streamflow of the Araguaia River, Brazil, Biogeochemistry, 105, 119131, https://doi.org/10.1007/s10533-011-9582-2, 2011.

Coe, M. T., Marthews, T. R., Costa, M. H., Galbraith, D. R., Greenglass, N. L., Imbuzeiro, H. M. A., Levine, N. M., Malhi, Y., Moorcroft, P. R., Muza, M. N., Powell, T. L., Saleska, S. R., Solorzano, L. A., and Wang, J.: Deforestation and climate feedbacks threaten the ecological integrity of southsoutheastern Amazonia, Philos. T. Roy. Soc. B, 368, 20120155, https://doi.org/10.1098/rstb.2012.0155, 2013.

Collischonn, B., Collischonn, W., and Tucci, C. E. M.: Daily hydrological modeling in the Amazon basin using TRMM rainfall estimates, J. Hydrol., 360, 207-216, https://doi.org/10.1016/j.jhydrol.2008.07.032, 2008.

Costa, M. H. and Foley, J. A.: Combined effects of deforestation and doubled atmospheric $\mathrm{CO}_{2}$ concentrations on the climate of Amazonia, J. Climate, 13, 18-34, https://doi.org/10.1175/15200442(2000)013<0018:CEODAD>2.0.CO;2, 2000.

Costa, M. H., Botta, A., and Cardille, J. A.: Effects of largescale changes in land cover on the discharge of the Tocantins River, Southeastern Amazonia, J. Hydrol., 283, 206-217, https://doi.org/10.1016/S0022-1694(03)00267-1, 2003.

D’Almeida, C., Vörösmarty, C. J., Marengo, J. A., Hurtt, G. C., Dingman, S. L., and Keim, B. D.: A water balance model to study the hydrological response to different scenarios of deforestation in Amazonia, J. Hydrol., 331, 125-136, https://doi.org/10.1016/j.jhydrol.2006.05.027, 2006.

D’Almeida, C., Vörösmarty, C. J., Hurtt, G. C., Marengo, J. A., Dingman, S. L., and Keim, B. D.: The effects of deforestation on the hydrological cycle in Amazonia: A review on scale and resolution, Int. J. Climatol., 27, 633-647, https://doi.org/10.1002/joc.1475, 2007.

Dee, D. P., Uppala, S. M., Simmons, A. J., Berrisford, P., Poli, P., Kobayashi, S., Andrae, U., Balmaseda, M. A., Balsamo, G., Bauer, P., Bechtold, P., Beljaars, A. C. M., van de Berg, L., Bidlot, J., Bormann, N., Delsol, C., Dragani, R., Fuentes, M., Geer, A. J., Haimberger, L., Healy, S. B., Hersbach, H., Hólm, E. V., Isaksen, L., Kållberg, P., Köhler, M., Matricardi, M., Mcnally, A. P., Monge-Sanz, B. M., Morcrette, J. J., Park, B. K., Peubey, C., de Rosnay, P., Tavolato, C., Thépaut, J. N., and Vitart, F.: The ERA-Interim reanalysis: Configuration and performance of the data assimilation system, Q. J. Roy. Meteorol. Soc., 137, 553597, https://doi.org/10.1002/qj.828, 2011.

Dickinson, R. E. and Henderson-Sellers, A.: Modelling tropical deforestation: A study of GCM land-surface 
parametrizations, Q. J. Roy. Meteorol. Soc., 114, 439-462, https://doi.org/10.1002/qj.49711448009, 1988.

Dirmeyer, P. A. and Brubaker, K. L.: Characterization of the Global Hydrologic Cycle from a Back-Trajectory Analysis of Atmospheric Water Vapor, J. Hydrometeorol., 8, 20-37, https://doi.org/10.1175/JHM557.1, 2007.

Dirmeyer, P. A. and Shukla, J.: Albedo as a modulator of climate response to tropical deforestation, J. Geophys. Res., 99, 20863, https://doi.org/10.1029/94JD01311, 1994.

Dirmeyer, P. A., Brubaker, K. L., and DelSole, T.: Import and export of atmospheric water vapor between nations, J. Hydrol., 365, 1122, https://doi.org/10.1016/j.jhydrol.2008.11.016, 2009.

Eltahir, E. A. B. and Bras, R. L.: Precipitation recycling in the Amazon basin, Q. J. Roy. Meteorol. Soc., 120, 861-880, https://doi.org/10.1002/qj.49712051806, 1994.

Eltahir, E. A. B. and Bras, R. L.: Precipitation recycling, Rev. Geophys., 34, 367-378, https://doi.org/10.1029/96RG01927, 1996.

Fisch, G., Tota, J., Machado, L. A. T., Silva Dias, M. A. F., da Lyra, R. F., Nobre, C. A., Dolman, A. J., and Gash, J. H. C.: The convective boundary layer over pasture and forest in Amazonia, Theor. Appl. Climatol., 78, 47-59, https://doi.org/10.1007/s00704-004-0043-x, 2004.

Fisher, J. B., Malhi, Y., Bonal, D., Da Rocha, H. R., De Araújo, A. C., Gamo, M., Goulden, M. L., Hirano, T., Huete, A. R., Kondo, H., Kumagai, T., Loescher, H. W., Miller, S., Nobre, A. D., Nouvellon, Y., Oberbauer, S. F., Panuthai, S., Roupsard, O., Saleska, S., Tanaka, K., Tanaka, N., Tu, K. P., and von Randow, C.: The land-atmosphere water flux in the tropics, Global Change Biol., 15, 2694-2714, https://doi.org/10.1111/j.13652486.2008.01813.x, 2009.

Fisher, R. A., Williams, M., de Lourdes Ruivo, M., de Costa, A. L., and Meir, P.: Evaluating climatic and soil water controls on evapotranspiration at two Amazonian rainforest sites, Agr. Forest Meteorol., 148, 850-861, https://doi.org/10.1016/j.agrformet.2007.12.001, 2008.

Foley, J. A., Costa, M. H., Delire, C., Ramankutty, N., and Snyder, P.: Green surprise? How terrestrial ecosystems could affect earth's climate, Front. Ecol. Environ., 1, 38-44, https://doi.org/10.1890/15409295(2003)001[0038:GSHTEC]2.0.CO;2, 2003.

Foley, J. A., Defries, R., Asner, G. P., Barford, C., Bonan, G., Carpenter, S. R., Chapin, F. S., Coe, M. T., Daily, G. C., Gibbs, H. K., Helkowski, J. H., Holloway, T., Howard, E. A., Kucharik, C. J., Monfreda, C., Patz, J. A., Prentice, I. C., Ramankutty, N., and Snyder, P. K.: Global consequences of land use, Science, 309, 570-574, https://doi.org/10.1126/science.1111772, 2005.

Foley, J. A., Asner, G. P., Costa, M. H., Coe, M. T., Defries, R., Gibbs, H. K., Howard, E. A., Olson, S., Patz, J., Ramankutty, N., and Snyder, P.: Amazonia revealed: forest degradation and loss of ecosystem goods and services in the Amazon Basin, Front. Ecol. Environ., 5, 25-32, https://doi.org/10.1890/15409295(2007)5[25:ARFDAL]2.0.CO;2, 2007.

Gedney, N. and Valdes, P. J.: The effect of Amazonian deforestation on the northern hemisphere circulation and climate, Geophys. Res. Lett., 27, 3053, https://doi.org/10.1029/2000GL011794, 2000 .

Goessling, H. F. and Reick, C. H.: On the "well-mixed" assumption and numerical 2-D tracing of atmospheric moisture, At- mos. Chem. Phys., 13, 5567-5585, https://doi.org/10.5194/acp13-5567-2013, 2013.

Gordon, L. J., Steffen, W., Jonsson, B. F., Folke, C., Falkenmark, M., and Johannessen, A.: Human modification of global water vapor flows from the land surface, P. Natl. Acad. Sci. USA, 102, 7612-7617, https://doi.org/10.1073/pnas.0500208102, 2005.

Hahmann, A. N. and Dickinson, R. E.: RCCM2 - BATS Model over Tropical South America: Applications to Tropical Deforestation, J. Climate, 10, 1944-1964, https://doi.org/10.1175/15200442(1997)010<1944:RBMOTS>2.0.CO;2, 1997.

Hansen, M. C., Potapov, P. V., Moore, R., Hancher, M., Turubanova, S. A., Tyukavina, A., Thau, D., Stehman, S. V., Goetz, S. J., Loveland, T. R., Kommareddy, A., Egorov, A., Chini, L., Justice, C. O., and Townshend, J. R. G.: High-Resolution Global Maps of 21st-Century Forest Cover Change, Science, 342, 850-853, https://doi.org/10.1126/science.1244693, 2013.

Henderson-Sellers, A., Dickinson, R. E., Durbidge, T. B., Kennedy, P. J., McGuffie, K., and Pitman, A. J.: Tropical deforestation: Modeling local- to regional-scale climate change, J. Geophys. Res.-Atmos., 98, 7289-7315, https://doi.org/10.1029/92JD02830, 1993.

Henderson-Sellers, A., McGuffie, K., and Zhang, H.: Stable isotopes as validation tools for global climate model predictions of the impact of Amazonian deforestation, J. Climate, 15, 2664-2677, https://doi.org/10.1175/15200442(2002)015<2664:SIAVTF>2.0.CO;2, 2002.

Huffman, G. J., Bolvin, D. T., Nelkin, E. J., Wolff, D. B., Adler, R. F., Gu, G., Hong, Y., Bowman, K. P., and Stocker, E. F.: The TRMM Multisatellite Precipitation Analysis (TMPA): Quasi-Global, Multiyear, Combined-Sensor Precipitation Estimates at Fine Scales, J. Hydrometeorol., 8, 38-55, https://doi.org/10.1175/JHM560.1, 2007.

INPE - Instituto Nacional de Pesquisas Espaciais: http://www.obt. inpe.br/prodes/index.php, last access: 19 July 2017.

Karam, H. N. and Bras, R. L.: Climatological Basin-Scale Amazonian Evapotranspiration Estimated through a Water Budget Analysis, J. Hydrometeorol., 9, 1048-1060, https://doi.org/10.1175/2008JHM888.1, 2008.

Keys, P. W., Van Der Ent, R. J., Gordon, L. J., Hoff, H., Nikoli, R., and Savenije, H. H. G.: Analyzing precipitationsheds to understand the vulnerability of rainfall dependent regions, Biogeosciences, 9, 733-746, https://doi.org/10.5194/bg-9-7332012, 2012.

Keys, P. W., Barnes, E. A., Van Der Ent, R. J., and Gordon, L. J.: Variability of moisture recycling using a precipitationshed framework, Hydrol. Earth Syst. Sci., 18, 3937-3950, https://doi.org/10.5194/hess-18-3937-2014, 2014.

Keys, P. W., Wang-Erlandsson, L., Gordon, L. J., Gemmill-Herren, B., LeBuhn, G., and Minckley, R.: Revealing Invisible Water: Moisture Recycling as an Ecosystem Service, PLoS One, 11, e0151993, https://doi.org/10.1371/journal.pone.0151993, 2016.

Keys, P. W., Wang-Erlandsson, L., Gordon, L. J., Galaz, V., and Ebbesson, J.: Approaching moisture recycling governance, Global Environ. Change, 45, 15-23, https://doi.org/10.1016/j.gloenvcha.2017.04.007, 2017.

Khanna, J. and Medvigy, D.: Strong control of surface roughness variations on the simulated dry season regional atmospheric response to contemporary deforestation in Ron- 
donia, Brazil, J. Geophys. Res.-Atmos., 119, 13067-13078, https://doi.org/10.1002/2014JD022278, 2014.

Khanna, J., Medvigy, D., Fueglistaler, S., and Walko, R.: Regional dry-season climate changes due to three decades of Amazonian deforestation, Nat. Clim. Change, 7, 200-204, https://doi.org/10.1038/nclimate3226, 2017.

Kim, H., Yeh, P. J. F., Oki, T., and Kanae, S.: Role of rivers in the seasonal variations of terrestrial water storage over global basins, Geophys. Res. Lett., 36, L17402, https://doi.org/10.1029/2009GL039006, 2009.

Kleidon, A. and Heimann, M.: Assessing the role of deep rooted vegetation in the climate system with model simulations: mechanism, comparison to observations and implications for Amazonian deforestation, Clim. Dynam., 16, 183-199, https://doi.org/10.1007/s003820050012, 2000.

Koren, I., Altaratz, O., Remer, L. A., Feingold, G., Martins, J. V., and Heiblum, R. H.: Aerosol-induced intensification of rain from the tropics to the mid-latitudes, Nat. Geosci., 5, 118-122, https://doi.org/10.1038/ngeo1364, 2012.

Koster, R. D., Jouzel, J., Suozzo, R., Russell, G., Broecker, W., Rind, D., and Eagleson, P.: Global sources of local precipitation as determined by the Nasa/Giss GCM, Geophys. Res. Lett., 13, 121-124, https://doi.org/10.1029/GL013i002p00121, 1986.

Koster, R. D., Dirmeyer, P. A., Guo, Z., Bonan, G., Chan, E., Cox, P., Gordon, C. T., Kanae, S., Kowalczyk, E., Lawrence, D., Liu, P., Lu, C.-H., Malyshev, S., McAvaney, B., Mitchell, K., Mocko, D., Oki, T., Oleson, K., Pitman, A., Sud, Y. C., Taylor, C. M., Verseghy, D., Vasic, R., Xue, Y., and Yamada, T.: Regions of Strong Coupling Between Soil Moisture and Precipitation, Science, 305, 1138-1140, https://doi.org/10.1126/science.1100217, 2004.

Laurance, W. F., Cochrane, M. A., Bergen, S., Fearnside, P. M., Delamônica, P., Barber, C., D’Angelo, S., and Fernandes, T.: Environment. The future of the Brazilian Amazon, Science, 291, 438-439, https://doi.org/10.1126/science.291.5503.438, 2001.

Lawrence, D. and Vandecar, K.: Effects of tropical deforestation on climate and agriculture, Nat. Clim. Change, 5, 27-34, https://doi.org/10.1038/nclimate2430, 2015.

Lean, J. and Rowntree, P. R.: Understanding the Sensitivity of a GCM Simulation of Amazonian Deforestation to the Specification of Vegetation and Soil Characteristics, J. Climate, 10, 1216-1235, https://doi.org/10.1175/15200442(1997)010<1216:UTSOAG>2.0.CO;2, 1997.

Lee, J.-E., Oliveira, R. S., Dawson, T. E., and Fung, I.: Root functioning modifies seasonal climate, P. Natl. Acad. Sci. USA, 102, 17576-17581, https://doi.org/10.1073/pnas.0508785102, 2005.

Lejeune, Q., Davin, E. L., Guillod, B. P., and Seneviratne, S. I.: Influence of Amazonian deforestation on the future evolution of regional surface fluxes, circulation, surface temperature and precipitation, Clim. Dynam., 44, 2769-2786, https://doi.org/10.1007/s00382-014-2203-8, 2015.

Lima, L. S., Coe, M. T., Soares Filho, B. S., Cuadra, S. V., Dias, L. C. P., Costa, M. H., Lima, L. S., and Rodrigues, H. O.: Feedbacks between deforestation, climate, and hydrology in the Southwestern Amazon: Implications for the provision of ecosystem services, Landsc. Ecol., 29, 261-274, https://doi.org/10.1007/s10980-013-9962-1, 2014.
Loarie, S. R., Lobell, D. B., Asner, G. P., Mu, Q., and Field, C. B.: Direct impacts on local climate of sugar-cane expansion in Brazil, Nat. Clim. Change, 1, 105-109, 2011.

Maeda, E. E., Ma, X., Wagner, F., Kim, H., Oki, T., Eamus, D., and Huete, A.: Evapotranspiration seasonality across the Amazon basin, Earth Syst. Dynam., 8, 439-454, https://doi.org/10.5194/esd-8-439-2017, 2017.

Mahmood, R., Pielke, R. A., Hubbard, K. G., Niyogi, D., Dirmeyer, P. A., Mcalpine, C., Carleton, A. M., Hale, R., Gameda, S., Beltrán-Przekurat, A., Baker, B., Mcnider, R., Legates, D. R., Shepherd, M., Du, J., Blanken, P. D., Frauenfeld, O. W., Nair, U. S., and Fall, S.: Land cover changes and their biogeophysical effects on climate, Int. J. Climatol., 34, 929-953, https://doi.org/10.1002/joc.3736, 2014.

Malhi, Y., Aragao, L. E. O. C., Galbraith, D., Huntingford, C., Fisher, R., Zelazowski, P., Sitch, S., McSweeney, C., and Meir, P.: Exploring the likelihood and mechanism of a climate-change-induced dieback of the Amazon rainforest, P. Natl. Acad. Sci. USA, 106, 20610-20615, https://doi.org/10.1073/pnas.0804619106, 2009.

Meir, P., Cox, P., and Grace, J.: The influence of terrestrial ecosystems on climate, Trends Ecol. Evol., 21, 254-260, https://doi.org/10.1016/j.tree.2006.03.005, 2006.

Miguez-Macho, G. and Fan, Y.: The role of groundwater in the Amazon water cycle: 1. Influence on seasonal streamflow, flooding and wetlands, J. Geophys. Res.-Atmos., 117, D15113, https://doi.org/10.1029/2012JD017539, 2012.

MINAM - Ministerio del Ambiente: http://geobosques.minam.gob. pe/, last access: 19 July 2017.

Mu, Q., Zhao, M., and Running, S. W.: MODIS Global Terrestrial Evapotranspiration (ET) Product (NASA MOD16A2/A3), Algorithm Theoretical Basis Document, Collection 5, NASA HQ, Numerical Terradynamic Simulation Group, University of Montana, Missoula, MT, USA, 20 November 2013.

Nepstad, D. C., Stickler, C. M., and Almeida, O. T.: Globalization of the Amazon soy and beef industries: Opportunities for conservation, Conserv. Biol., 20, 1595-1603, https://doi.org/10.1111/j.1523-1739.2006.00510.x, 2006.

Nepstad, D. C., Stickler, C. M., Filho, B. S., and Merry, F.: Interactions among Amazon land use, forests and climate: prospects for a near-term forest tipping point, Philos. T. Roy. Soc. B, 363, 1737-1746, https://doi.org/10.1098/rstb.2007.0036, 2008.

Niu, G.-Y., Yang, Z.-L., Dickinson, R. E., Gulden, L. E., and $\mathrm{Su}, \mathrm{H}$.: Development of a simple groundwater model for use in climate models and evaluation with Gravity Recovery and Climate Experiment data, J. Geophys. Res., 112, D07103, https://doi.org/10.1029/2006JD007522, 2007.

Panday, P. K., Coe, M. T., Macedo, M. N., Lefebvre, P., and de Castanho, A. D. A.: Deforestation offsets water balance changes due to climate variability in the Xingu River in eastern Amazonia, J. Hydrol., 523, 822-829, https://doi.org/10.1016/j.jhydrol.2015.02.018, 2015.

Pielke, R. A., Marland, G., Betts, R. A., Chase, T. N., Eastman, J. L., Niles, J. O., Niyogi, D. D. S., and Running, S. W.: The influence of land-use change and landscape dynamics on the climate system: relevance to climate-change policy beyond the radiative effect of greenhouse gases, Philos. T. Roy. Soc. A, 360, 17051719, https://doi.org/10.1098/rsta.2002.1027, 2002. 
Pires, G. F. and Costa, M. H.: Deforestation causes different subregional effects on the Amazon bioclimatic equilibrium, Geophys. Res. Lett., 40, 3618-3623, https://doi.org/10.1002/grl.50570, 2013.

Pitman, A. J. and Lorenz, R.: Scale dependence of the simulated impact of Amazonian deforestation on regional climate, Environ. Res. Lett., 11, 094025, https://doi.org/10.1088/17489326/11/9/094025, 2016.

Piu, H. C. and Menton, M.: The context of REDD+ in Peru: Drivers, agents and institutions, Occasional Paper 106, Center for International Forestry Research, Bogor, Indonesia, 2014.

Pokhrel, Y. N., Fan, Y., Miguez-Macho, G., Yeh, P. J. F., and Han, S. C.: The role of groundwater in the Amazon water cycle: 3. Influence on terrestrial water storage computations and comparison with GRACE, J. Geophys. Res.-Atmos., 118, 3233-3244, https://doi.org/10.1002/jgrd.50335, 2013.

Rodell, M. and Famiglietti, J. S.: The potential for satellite-based monitoring of groundwater storage changes using GRACE: The High Plains aquifer, Central US, J. Hydrol., 263, 245-256, https://doi.org/10.1016/S0022-1694(02)00060-4, 2002.

Sakai, R. K., Fitzjarrald, D. R., Moraes, O. L. L., Staebler, R. M., Acevedo, O. C., Czikowsky, M. J., Da Silva, R., Brait, E., and Miranda, V.: Land-use change effects on local energy, water, and carbon balances in an Amazonian agricultural field, Global Change Biol., 10, 895-907, https://doi.org/10.1111/j.15298817.2003.00773.x, 2004.

Salati, E. and Nobre, C. A.: Possible climatic impacts of tropical deforestation, Climatic Change, 19, 177-196, https://doi.org/10.1007/BF00142225, 1991.

Salati, E., Dall'Olio, A., Matsui, E., and Gat, J. R.: Recycling of water in the Amazon Basin: An isotopic study, Water Resour. Res., 15, 1250-1258, https://doi.org/10.1029/WR015i005p01250, 1979.

Seneviratne, S. I., Lüthi, D., Litschi, M., and Schär, C.: Landatmosphere coupling and climate change in Europe, Nature, 443, 205-209, https://doi.org/10.1038/nature05095, 2006.

Shukla, J., Nobre, C., and Sellers, P.: Amazon Deforestation and Climate Change, Science, 247, 1322-1325, https://doi.org/10.1126/science.247.4948.1322, 1990.

Silvério, D. V., Brando, P. M., Macedo, M. N., Beck, P. S. A., Bustamante, M., and Coe, M. T.: Agricultural expansion dominates climate changes in southeastern Amazonia: the overlooked non-GHG forcing, Environ. Res. Lett., 10, 104015, https://doi.org/10.1088/1748-9326/10/10/104015, 2015.

Snyder, P. K.: The Influence of Tropical Deforestation on the Northern Hemisphere Climate by Atmospheric Teleconnections, Earth Interact., 14, 1-34, https://doi.org/10.1175/2010EI280.1, 2010.

Soares-Filho, B. S., Nepstad, D. C., Curran, L. M., Cerqueira, G. C., Garcia, R. A., Ramos, C. A., Voll, E., McDonald, A., Lefebvre, P., and Schlesinger, P.: Modelling conservation in the Amazon basin, Nature, 440, 520-523, https://doi.org/10.1038/nature04389, 2006.

Soares-Filho, B. S., Rajao, R., Macedo, M., Carneiro, A., Costa, W., Coe, M., Rodrigues, H., and Alencar, A.: Cracking Brazil's Forest Code, Science, 344, 363-364, https://doi.org/10.1126/science.1246663, 2014.

Spracklen, D. V. and Garcia-Carreras, L.: The impact of Amazonian deforestation on Amazon basin rainfall, Geophys. Res. Lett., 42, 9546-9552, https://doi.org/10.1002/2015GL066063, 2015.
Spracklen, D. V., Arnold, S. R., and Taylor, C. M.: Observations of increased tropical rainfall preceded by air passage over forests, Nature, 489, 282-285, https://doi.org/10.1038/nature11390, 2012.

Su, F., Hong, Y., and Lettenmaier, D. P.: Evaluation of TRMM Multisatellite Precipitation Analysis (TMPA) and Its Utility in Hydrologic Prediction in the La Plata Basin, J. Hydrometeorol., 9, 622-640, https://doi.org/10.1175/2007JHM944.1, 2008.

Swann, A. L. S., Longo, M., Knox, R. G., Lee, E., and Moorcroft, P. R.: Future deforestation in the Amazon and consequences for South American climate, Agr. Forest Meteorol., 214-215, 12-24, https://doi.org/10.1016/j.agrformet.2015.07.006, 2015.

Tapley, B. D.: GRACE Measurements of Mass Variability in the Earth System, Science, 305, 503-505, https://doi.org/10.1126/science.1099192, 2004.

Tian, L., Yao, T., MacClune, K., White, J. W. C., Schilla, A., Vaughn, B., Vachon, R., and Ichiyanagi, K.: Stable isotopic variations in west China: A consideration of moisture sources, J. Geophys. Res.-Atmos., 112, D10112, https://doi.org/10.1029/2006JD007718, 2007.

Trenberth, K. E.: Atmospheric moisture recycling: Role of advection and local evaporation, J. Climate, 12, 1368-1381, https://doi.org/10.1175/15200442(1999)012<1368:AMRROA>2.0.CO;2, 1999.

Tuinenburg, O. A., Hutjes, R. W. A., and Kabat, P.: The fate of evaporated water from the Ganges basin, J. Geophys. Res.-Atmos., 117, D01107, https://doi.org/10.1029/2011JD016221, 2012.

Van Der Ent, R. J., Savenije, H. H. G., Schaefli, B., and Steele-Dunne, S. C.: Origin and fate of atmospheric moisture over continents, Water Resour. Res., 46, W09525, https://doi.org/10.1029/2010WR009127, 2010.

Van der Ent, R. J., Tuinenburg, O. A., Knoche, H.-R., Kunstmann, H., and Savenije, H. H. G.: Should we use a simple or complex model for moisture recycling and atmospheric moisture tracking?, Hydrol. Earth Syst. Sci., 17, 4869-4884, https://doi.org/10.5194/hess-17-4869-2013, 2013.

Van Der Ent, R. J., Wang-Erlandsson, L., Keys, P. W., and Savenije, H. H. G.: Contrasting roles of interception and transpiration in the hydrological cycle - Part 2: Moisture recycling, Earth Syst. Dynam., 5, 471-489, https://doi.org/10.5194/esd-5-4712014, 2014.

Veiga, J. B., Tourrand, J. F., and Piketty, M. G.: Cattle ranching in the amazon rainforest, Proc. Aust. Soc. Anim. Prod., 24, 253256, 2002.

Victoria, R. L., Martinelli, L. A., Mortatti, J., and Richey, J.: Mechanisms of Water Recycling in the Amazon Basin - Isotopic Insights, Ambio, 20, 384-387, 1991.

Voldoire, A. and Royer, J. F.: Tropical deforestation and climate variability, Clim. Dynam., 22, 857-874, https://doi.org/10.1007/s00382-004-0423-z, 2004.

Wagner, S., Kunstmann, H., Bárdossy, A., Conrad, C., and Colditz, R. R.: Water balance estimation of a poorly gauged catchment in West Africa using dynamically downscaled meteorological fields and remote sensing information, Phys. Chem. Earth, 34, 225235, https://doi.org/10.1016/j.pce.2008.04.002, 2009.

Wang-Erlandsson, L., Fetzer, I., Keys, P. W., van der Ent, R. J., Savenije, H. H. G., and Gordon, L. J.: Remote land use impacts on river flows through atmospheric teleconnections, Hydrol. 
Earth Syst. Sci. Discuss., https://doi.org/10.5194/hess-2017-494, in review, 2017.

Werth, D. and Avissar, R.: The Regional Evapotranspiration of the Amazon, J. Hydrometeorol., 5, 100-109, https://doi.org/10.1175/15257541(2004)005<0100:TREOTA>2.0.CO;2, 2004.

Yeh, P. J.-F. and Famiglietti, J. S.: Regional Groundwater Evapotranspiration in Illinois, J. Hydrometeorol., 10, 464-478, https://doi.org/10.1175/2008JHM1018.1, 2009.

Yoshimura, K., Oki, T., Ohte, N., and Kanae, S.: Colored Moisture Analysis Estimates of Variations in 1998 Asian Monsoon Water Sources, J. Meteorol. Soc. Jpn., 82, 1315-1329, https://doi.org/10.2151/jmsj.2004.1315, 2004.

Zemp, D. C., Schleussner, C. F., Barbosa, H. M. J., Van Der Ent, R. J., Donges, J. F., Heinke, J., Sampaio, G., and Rammig, A.: On the importance of cascading moisture recycling in South America, Atmos. Chem. Phys., 14, 13337-13359, https://doi.org/10.5194/acp-14-13337-2014, 2014.
Zemp, D. C., Schleussner, C.-F., Barbosa, H. M. J., Hirota, M., Montade, V., Sampaio, G., Staal, A., Wang-Erlandsson, L., and Rammig, A.: Self-amplified Amazon forest loss due to vegetation-atmosphere feedbacks, Nat. Commun., 8, 14681, https://doi.org/10.1038/ncomms14681, 2017a.

Zemp, D. C., Schleussner, C. F., Barbosa, H. M. J., and Rammig, A.: Deforestation effects on Amazon forest resilience, Geophys. Res. Lett., 44, 6182-6190, https://doi.org/10.1002/2017GL072955, $2017 b$. 